iRASD Journal of Economics

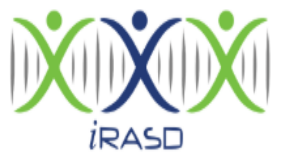

Volume 3, Number 3, 2021, Pages 281 - 292

Journal Home Page:

https://journals.internationalrasd.org/index.php/joe

\title{
The Effects of Green Financial Development on Economic Growth in Pakistan
}

\author{
Muhammad Atif Nawaz ${ }^{1}$, Muhammad Sajjad Hussain², Altaf Hussain ${ }^{3}$ \\ ${ }^{1}$ Department of Economics, The Islamia University of Bahawalpur, Pakistan. Email: atif.nawaz.baloch@gmail.com \\ ${ }^{2}$ Visiting Faculty, Superior University Lahore, Pakistan. Email: sajjadgift@gmail.com \\ ${ }^{3}$ Assistant Professor, Department of Economics, The Islamia University of Bahawalpur, Pakistan. \\ Email: altafhussain@iub.edu.pk
}

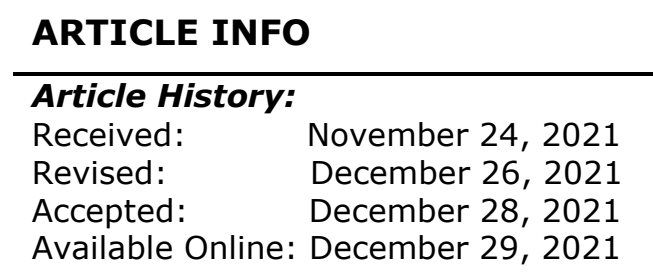

\section{Keywords:}

Green financial development

Green credit

Green securities

Green insurance

Green investment

Foreign direct investment

Economic growth

JEL Classification Codes:

E51, F43, F52, G22, O16

\begin{abstract}
Sustainable development is now a mantra for which every country is striving for it and green finance, and green financial development which is advancement in financial activities harmonized with environmental protection and ecological balance, is considered as the foremost solution for it. Keeping in view the importance of green financial development for the economic growth, this study aims to examine the effects of green financial development such as green credit, green securities, green insurance, green investment, and foreign direct investment on the economic growth of Pakistan. The time series has extracted from World Development Indicators (WDI) and State Bank of Pakistan (SBP) for the period 1981 to 2019. For the analysis purpose, Autoregressive distributive lag (ARDL) and Granger casualty have been executed. The findings established empirically that green financial development such as green credit, green securities, green insurance, green investment, and foreign direct investment have a positive impact on the economic growth of Pakistan. These findings provide the insight to the regulators that they should enhance their focus towards green financial development that is imperative for the economic growth of the country.
\end{abstract}

(c) 2021 The Authors, Published by iRASD. This is an Open Access Article under the Creative Common Attribution Non-Commercial 4.0

Corresponding Author's Email: altafhussain@iub.edu.pk

\section{Introduction}

All the economic sectors such as manufacturing, trading, mining, and tourism, etc. are affected by the amendments or advancements in the policies of the financial institutions and government as these policies and regulations affect financial sources of the business enterprises. Mostly the business organization carries their business on credit, borrowed money, and capital acquired through the issuance of securities to the outsiders; so, these organizations are much affected by the amendments in financial policies, and turn affect the overall economic growth of the country (M. K. Hassan, Sanchez, \& Yu, 2011). Therefore, the green financial development influences the business organizational structure, their operations, and thus their contribution into the GDP or economic growth. Almost all the economies are focusing on environmental attachments to financial policies and agreements for better economic consequences (Zhang, Wang, \& Wang, 2012). 
This study has been conducted to analyze different forms of green financial development and their influences on the economy and its growth. The measurements of financial development are green credit, green insurance, green investment, and the use of foreign direct investment for green innovation purposes. Ahmad, Hussain, Umer, and Parveen (2017) suggested to increase the loan amount for small firms to train the employees to be very efficient. The credit policy which is designed in the way that the credit should be granted for the institutions which carry out their operations keeping under consideration the environmental requirements of regulators and customers on the easy conditions give way to the organizations for development (R. Liu, Wang, Zhang, \& Zhang, 2019). Similarly, the green securities do not affect the heart or other organs of the holders, their health would be safe, and they can take an active part in the economic activities contributing to the economic growth. Likewise, the introduction of green practices in the insurance policies removes the harmful infrastructure from business building and their operations, the better-quality infrastructure gives better economic consequences. Green investment is a part of green financial development as it encourages projects which minimize the pollutants and raises the level of organizations' overall performance in an economy. Last but not least, foreign direct investment is encouraged by the host government to promote environmental innovation in the country (He, Liu, Zhong, Wang, \& Xia, 2019).

This research study has been conducted to analyze the contribution of green financial development in the economy of Pakistan. It is a developing economy with $\$ 276$ billion GDP as per the statistics of 2019 according to which it is the $40^{\text {th }}$ largest country in the world economy. The GDP growth rate has been decreasing in recent years due to several economic, political, and environmental problems. Many of these problems can be solved by creating environmental awareness in the individuals and economic sectors (S. T. Hassan, Xia, Khan, \& Shah, 2019). The major economic sectors of Pakistan's economy are agriculture whose share in the GDP is $18.76 \%$, industrial sector with the GDP share of $19.74 \%$, and contributions of service sector is $61.52 \%$ to country's GDP. The major portion of the economy is covered by the service sector in which the financial service sector affects all the other economic sectors as it is considered necessary for financial sources. Thus, the change in the policies of financial institutions affects the operational and financial performance of other business organizations, and thereby, it brings a change in the economic growth rate of Pakistan (Luqman, Ahmad, \& Bakhsh, 2019).

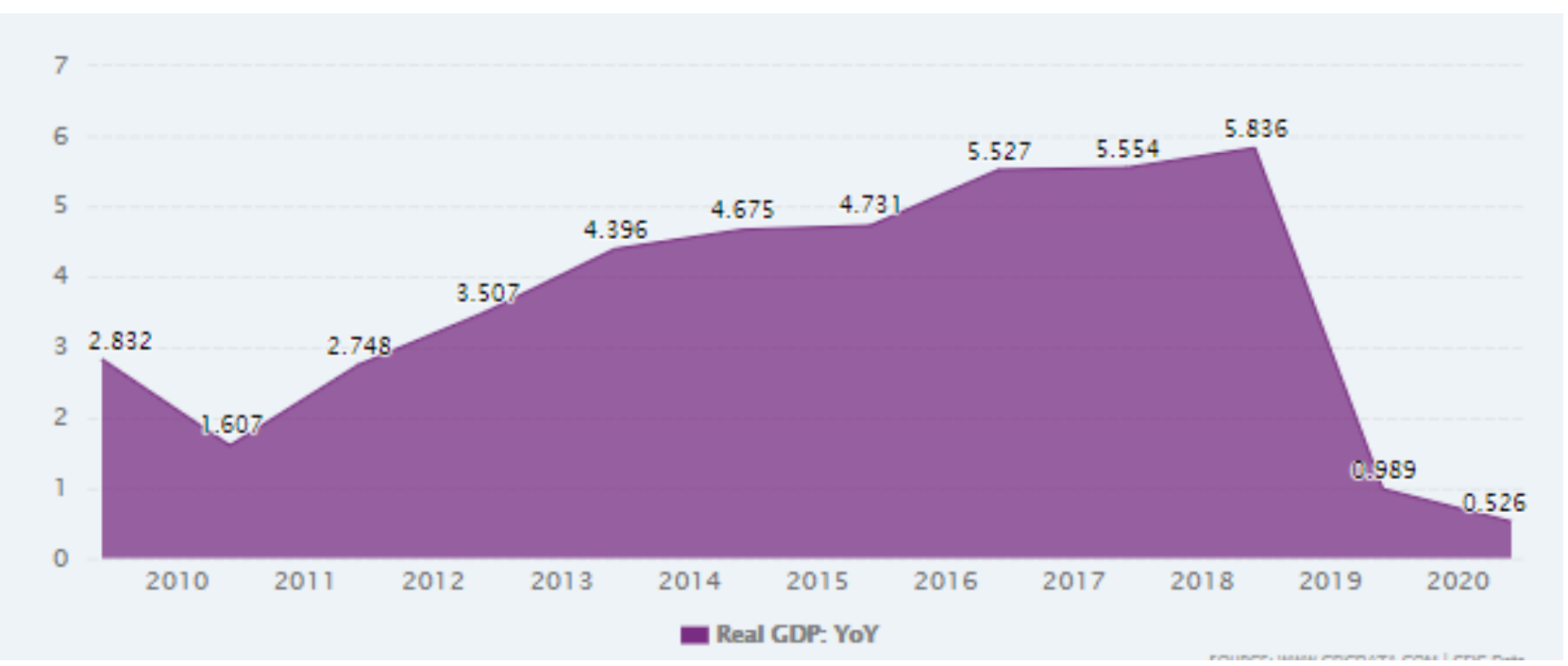

Figure 1: Pakistan's GPD after green financial development

In 2019 , the foreign exchange earnings through exports are $\$ 26$ billion, and the major export goods include textiles $(\$ 12,783$ million), food $(\$ 4,534$ million), chemical and pharmaceutical products ( $\$ 1,056$ million), leather manufacturers ( $\$ 479$ million), and petroleum (\$369 million). The textile, leather, chemical, and petroleum and manufacturing industries are 
essential in Pakistan's economy, but they create pollution in the country in the form of hazardous gases, oil, or water, and destroy the natural resources, and damage the health of the general public (Chandio, Jiang, \& Rehman, 2019). But green financial development like green financing, green credits, eco-friendly advancements in the policies of insurance companies, encouragement of investment in green projects not only by countrymen but also by foreigners, and green securities. This green financial development creates environmental consciousness thereby green innovation results in efficient performance of business organizations and help the country in raising the GDP and improving the ranking in the world economy. The major portion of the economy is based on services sector that are dependent on human resources. If the labor force is healthy and have conducive ecological work environment only then they can perform better, in other words, render their services efficiently that can be ensured by green financial advancements (Shah, 2019). The contribution of green financial development to Pakistan's economic growth rate becomes apparent from the following Figure 1.

\section{Literature Review}

As green financial development has a vital role in the stimulation of economic activities and the economic growth of the country, it has a dominant position in the literature, but still, investigation about the topic is needed. The literary article of Tan, Chen, Shi, and Wang (2014) states that the conditional attachment of the environmental aspects to the financial policies of the government and financial institutions give avenues to environmental innovation in the country and thus, helps in maintaining stability in the economic activities and ensuring healthy and active workforce that is conducive to economic growth. This study proves this fact with evidence for the economy of China. Similarly, a study by Shahbaz, Khan, and Tahir (2013) elaborate that the green financial development like green credit cards, green credit policies, ecofriendly debt and equity securities, green innovations in insurance, and green investment both from local organizations and foreign investors provide safe work environment and healthy active force which is considered the backbone of the economy.

In an economy, credit plays a tremendous role as it provides financial support to business enterprises involved in different economic sectors. The literary work out F. Wang, Yang, Reisner, and Liu (2019) on a green financial contribution to the economic growth, examines the initiation of financial service enterprises in producing green credits. This analysis implies that the financial institutions like banks are diverting their attention to the green improvement in their credit policies which meet the requirements of the public, customers, and government regulators about the environmental aspects. The environmentally friendly inscriptions introduced in the credit policies include applying green material in credit cards or credit documentation, allowing credits for eco-friendly projects, and eco-friendly conditions of allowing credits. Credit cards like Barclaycard's Breathe credit do spread toxic chemicals, and that can be easily recycled without causing harmful damages to health or natural resources (X. Liu, Wang, \& Cai, 2019). The environmentally conscious consumers mostly show a keen interest in holding such breath cards which do not affect their health and working capacity. The people holding eco-friendly cards show an excellent contribution to economic growth. Nawaz, Yousaf, Hussain, and Riaz (2020) maintained that tourism sector plays an important role in economic growth to the destination country but tourist activities can also increase the $\mathrm{CO}_{2}$ emissions. The use of breath cards and issuance of credits for eco-friendly projects like construction of the eco-friendly building, ecofriendly drainage of water, and implementation of eco-friendly technology in industries leads to financial and industrial development. It thereby accelerates economic growth of the country (Aizawa \& Yang, 2010). In Pakistan, these eco-friendly amendments in credit policies of the financial institutions have led to a higher GDP by raising their operational and financial performance through superior environmental performance.

The study by $\mathrm{H}$. Wang and Bernell (2013) provides deep insight into the high rate of economic growth through better financial development in the country. It clarifies the fact that the policy of management of financial institutions in the leading economies to determine the 
nature of securities, the material used in that instruments, and conditions of the issuance of securities under the consideration of environmental requirements of government regulators accelerate the rate of economic growth. The empirical study of Yong-hui (2010) in the operations of financial institutions implies that issuance of green securities both the debt securities and equity securities help derive better financial performance gaining the trust of the general public and general authorities and thereby derives economic growth of the country too. The effort of financial institutions to launch green debenture programs under which mostly is paid just to companies which ensure the regulators about environmental safety from their activities promotes different sectors in the economy and set higher economic growth rate. It has also been analyzed by Rydqvist, Spizman, and Strebulaev (2014) many governments are taking steps to tend the financial sector to establish climate action strategy which helps promote all the economic sectors with low-carbon, low-harmful chemical emission, and improved-health goals. Nawaz, Hussain, et al. (2020) argued that carbon emissions affect GDP negatively so bounding conditions should be attached to the credit utilization. Nawaz, Seshadri, et al. (2020) contended that $\mathrm{CO}_{2}$ emissions, Human Development Index, and investment in the energy sector have an impact on green finance and ultimately in the climate change.

In the emerging economies, financial service enterprises are the major business enterprises showing keen interest in the environment. In this case, insurance companies and several banks are introducing green insurance which helps in reducing the negative impacts of different business' resources and procedures. Shair et al. (2021) argued that banks without effective policies are subject to credit and liquidity risk and this risk have negative impact of total factor productivity of the overall economy. Fossil fuels deplete natural resources and spread pollution in the business and natural environment and several insurers whose basic objective is to protect the environment give discounts for the purchase of insurance for eco-friendly vehicles that do not create hazardous gases. It has been analyzed that several automobile insurances or boat insurance give discounts on the acquisition of hybrid vehicles or hybrid yacht and boats. Also, they provide opportunities for the insured to replace their traditional vehicles with the new comparable hybrid vehicles; the green insurance is of great importance in an economy as they ensure superior marketing and also provides healthy and efficient workers to the economy (Kuo, Lin, \& Hsu, 2016). Similarly, the green insurers give a discount on the cars using alternative energy sources like biodiesel, electricity, hydrogen, or natural gas which lower negative impacts on the environment and save natural resources and human resources to be used in the economy. Additionally, it has been investigated in the research work conducted by Sörensen and Emilsson (2019) that there are a large number of green commercial property insurance policies and endorsements in different business areas. For instance, the insurance policy installs green building systems and relevant material as it replaces the traditional buildings after bearing the loss. In these eco-friendly replacements include energy-efficient electrical equipment, conserving plumbing, and non-contaminating carpeting, and low odor paints (ZENG \& ZHANG, 2011). The Pakistani economy is constantly emerging because of the application of green insurance which is a part of green financial development in the country.

Green investment is one of the aspects of green financial development strategies which prove to be helpful for any country that intends to raise its position in the world economy with a better GDP rate. These studies elaborate that green investment is an act of placing capital into the projects with motive to provide environmental benefits (Eyraud, Clements, \& Wane, 2013). This financial activity is undertaken by individuals, particular equity firms, corporations, or hedge funds as well. This study concludes that environmental improvement is likely to improve the economy where there is a high tendency of green investment. As, Martin and Moser (2016) state in his investigation that the investment by particular organizations which carry out eco-friendly operational procedures, production activities, and environmentally friendly marketing along with green advertisement raises the profitability rate as the reduction of wastes, contaminating material, and emission of toxic gases raises marketing. The encouragement of investment by business enterprises in waste management, pollution reduction, improved energy research, and fossil fuel reduction project provides a sound basis to the economy (Karásek \& Pavlica, 2016). 
The investments in solar projects and electrification products are needed for sustainability not only for the environment but also for the economy (Sun et al., 2020). The green investment protects the natural environment and thereby the health of the people who actively perform their activities in business enterprises, and thus, they make a tremendous contribution to economic growth.

Moran (2012) suggests that green financial development through the encouragement of foreign direct investment puts a significant impact on the economic growth rate. External funding sources in the form of foreign direct investment encourage the host country's organizations to accelerate innovative ideas with technological improvements, and it has the potential to increase employment opportunities. The financial objectives, along with environmental consciousness, promote sustainable environmental innovations. Such environmental consciousness leads to a reduction of industrial pollutants, which causes high mortality and health issues (Alfaro, Chanda, Kalemli-Ozcan, \& Sayek, 2010). The encouragement of environmentally friendly foreign direct investment gives away to the innovative environmentally conscious technical and technological advancements in the business organizations in the host country. The advanced techniques and technologies lead to better operations, production, and marketing in the host economic organizations and thus, improve the economic growth rate. The economic regulators design their financial policies as the foreign direct investment should be used in the projects whose objective is to promote green innovations along with the high profit earning so that natural environment can be saved from the toxic gases, hazardous chemical and other material emitted from different industries (Shahbaz, Nasreen, Abbas, \& Anis, 2015). In the same way, the favorable use of foreign direct investment for in the programs creating environmental consciousness in the general people and the personal of business organizations help expand production and market both at national and international level which indicates higher economic growth of the host country.

\section{Research Methods}

The present study goal is to examine the effects of green credit, green securities, green insurance, green investment, and foreign direct investment as measures of green financial development on the economic growth of Pakistan. For this goal, the present study has extracted the data from WDI and SBP from 1981 to 2019. Thus, based on the reviewed literature, the present research has formulated the following estimation equation:

$E G_{t}=\alpha_{0}+\beta_{1} G C_{t}+\beta_{2} G S_{t}+\beta_{3} G I_{t}+\beta_{4} G I N V_{t}+\beta_{5} F D I_{t}+e_{t}$

Where;

$\mathrm{EG}=$ Economic Growth

$t=$ Time Period

$\mathrm{GC}=$ Green Credit

$\mathrm{GS}=$ Green Securities

$\mathrm{GI}=$ Green Insurance

GINV = Green Investment

FDI $=$ Foreign Direct Investment

The economic growth that is used as dependent variable in this study is measured as the GDP growth (annual \%) while green credit has been used as an independent variable and measured as the total green credit of banks divided by the total loans of banks. In addition, green securities and green insurance have also been adopted as determinants of economic growth that are measured as the total market value of environmental protection companies divided by the total market value of all shares listed on the stock exchange along with FDI that has also taken as a factor of economic growth. The green investment is measured as the fiscal expenditure of energy-saving and environmental-protection industries divided by the total fiscal 
expenditure and FDI is measured as foreign direct investment, net inflows as percentage of GDP. These measurements, along with variables, are shown in Table 2.

\section{Table 2}

\section{Variables with Measurements}

\begin{tabular}{|c|c|c|c|}
\hline S\# & Variables & Measurement & Sources \\
\hline 01 & Economic Growth & GDP growth (annual \%) & World Bank Database \\
\hline 02 & Green Credit & $\begin{array}{l}\text { Total green credit of banks / Total loans of } \\
\text { banks }\end{array}$ & State Bank of Pakistan \\
\hline 03 & Green Securities & $\begin{array}{l}\text { The total market value of environmental } \\
\text { protection companies / Total market } \\
\text { value of A-shares }\end{array}$ & World Bank Database \\
\hline 04 & Green Insurance & $\begin{array}{l}\text { Agricultural insurance expenditure / } \\
\text { Total insurance expenditure }\end{array}$ & State Bank of Pakistan \\
\hline 05 & Green Investment & $\begin{array}{l}\text { Fiscal expenditure of energy-saving } \\
\text { and environmental-protection industries /Total } \\
\quad \text { fiscal expenditure }\end{array}$ & World Bank Database \\
\hline 06 & $\begin{array}{l}\text { Foreign Direct } \\
\text { Investment }\end{array}$ & $\begin{array}{l}\text { Foreign direct investment, net inflows ( } \% \text { of } \\
\text { GDP) }\end{array}$ & World Bank Database \\
\hline
\end{tabular}

The findings of the study include the Augmented Dickey-Fuller (ADF) unit root test that shows the stationarity of the variables. This test is necessary to implement the appropriate statistical model on the variables. The estimation equation for the ADF test is given below:

$d\left(Y_{t}\right)=\alpha_{0}+\beta t+\gamma Y_{t-1}+d\left(Y_{t}(-1)\right)+\varepsilon_{t}$

The stationarity of all constructs has been investigated by using the ADF unit root test, and the estimation models of each construct are given below:

$$
\begin{aligned}
& d\left(E G_{t}\right)=\alpha_{0}+\beta t+\gamma E G_{t-1}+d\left(E G_{t}(-1)\right)+\varepsilon_{t} \\
& d\left(G C_{t}\right)=\alpha_{0}+\beta t+\gamma G C_{t-1}+d\left(G C_{t}(-1)\right)+\varepsilon_{t} \\
& d\left(G S_{t}\right)=\alpha_{0}+\beta t+\gamma G S_{t-1}+d\left(G S_{t}(-1)\right)+\varepsilon_{t} \\
& d\left(G I_{t}\right)=\alpha_{0}+\beta t+\gamma G I_{t-1}+d\left(G I_{t}(-1)\right)+\varepsilon_{t} \\
& d\left(G I N V_{t}\right)=\alpha_{0}+\beta t+\gamma G I N V_{t-1}+d\left(G I N V_{t}(-1)\right)+\varepsilon_{t} \\
& d\left(F D I_{t}\right)=\alpha_{0}+\beta t+\gamma F D I_{t-1}+d\left(F D I_{t}(-1)\right)+\varepsilon_{t}
\end{aligned}
$$

In addition, for the analysis of nexus among the variables, the present study has adopted and executed the ARDL model by using E-views. For ARDL estimation, firstly co-integration among the variables has been examined by using ARDL bond test. The estimation equation of the bond test is given below:

$$
\begin{gathered}
\Delta E G_{t}=\alpha_{0}+\sum \delta_{1} \Delta E G_{t-1}+\sum \delta_{2} \Delta G C_{t-1}+\sum \delta_{3} \Delta G S_{t-1}+\sum \delta_{4} \Delta G I_{t-1}+\sum \delta_{5} \Delta G I N V_{t-1}+\sum \delta_{6} \Delta F D I_{t-1}+ \\
\varphi_{1} E G_{t-1}+\varphi_{2} G C_{t-1}+\varphi_{3} G S_{t-1}+\varphi_{4} G I_{t-1}+\varphi_{5} G I N V_{t-1}+\varphi_{6} F D I_{t-1}+\varepsilon_{1}
\end{gathered}
$$

When the co-integration exists in the model than the present study estimated the error correction model and the estimation equation is as follow:

$$
\begin{gathered}
\Delta E G_{t}=\alpha_{0}+\sum \delta_{1} \Delta E G_{t-1}+\sum \varphi_{2} \Delta G C_{t-1}+\sum \omega_{3} \Delta G S_{t-1}+\sum \theta_{4} \Delta G I_{t-1}+\sum \phi_{5} \Delta G I N V_{t-1}+\sum \Upsilon_{6} \Delta F D I_{t-1}+\delta E C M_{t}+ \\
v_{t}
\end{gathered}
$$

Finally, the existing research has also checked Granger casualty test to examine the nexus among the variables on both side, and estimation models are as follow:

$Y_{t}=\beta_{0}+\sum_{j=1} \beta_{1 j} Y_{t-1}+\sum_{h=1} \beta_{2 h} Y_{t-p}+\varepsilon_{t}$

$X_{t}=\dot{\alpha}_{0}+\sum_{s=1} \dot{\alpha}_{1 s} Y_{t-s}+\sum_{t=1} \dot{\alpha}_{2 t} X_{t-m}+\varepsilon_{t}$ 


\section{Findings}

This section shows the descriptive statistics such as the minimum, maximum values along with mean and standard deviations of the variables. The statistics show that economic growth in Pakistan on average is 1.831 per cent of GDP. In addition, green credit on average is 1.14 green securities are on average is 1.73 , on average green insurance is 5.831 while green investment is 22.434 and FDI is .266. These statistics have been shown in Table 2.

Table 2

Descriptive Statistics

\begin{tabular}{cccccc}
\hline Variable & Obs. & Mean & Std. Dev. & Min & Max \\
\hline EG & 39 & 1.831 & .327 & 1.215 & 2.733 \\
GC & 39 & 1.14 & .082 & 1.009 & 1.319 \\
FDI & 39 & .266 & .192 & 0.057 & .569 \\
GS & 39 & 1.73 & .266 & 1.21 & 2.22 \\
GI & 39 & 5.831 & .311 & 5.162 & 6.399 \\
GINV & 39 & 22.434 & 4.828 & 15.47 & 33.65 \\
\hline
\end{tabular}

The correlation matrix shows the nexus among constructs along with multicollinearity issue and the findings show that the values are less than 0.90 that means no issue of multicollinearity in the model and positive association among all the predictors and economic growth of Pakistan. These figures are mentioned in Table 3.

Table 3

Matrix of Correlations

\begin{tabular}{lrrrrrr}
\hline \multicolumn{1}{c}{ Variables } & EG & GC & FDI & GS & GI & GINV \\
\hline EG & 1.000 & & & & & \\
GC & 0.125 & 1.000 & & & & \\
FDI & 0.230 & -0.501 & 1.000 & & & \\
GS & 0.134 & 0.214 & -0.109 & 1.000 & & \\
GI & 0.035 & 0.628 & -0.331 & 0.042 & 1.000 & \\
GINV & 0.057 & -0.102 & -0.078 & 0.577 & -0.551 & 1.000 \\
\hline
\end{tabular}

The results of the ADF unit root show that economic growth, green credit, green securities and green investment are stationary at a level while FDI and green insurance are stationary at first difference. These outcomes show the ARDL model is appropriate for the study. These statistics are shown in Table 4.

Table 4

Unit Root Test

\begin{tabular}{lccc}
\hline Augmented Dickey-Fuller Test (ADF) & Level & t-statistics & p-values \\
\hline EG & I(0) & -2.9564 & 0.0483 \\
GC & I(0) & -3.1229 & 0.0332 \\
FDI & I(1) & -6.0542 & 0.0000 \\
GS & I(0) & -5.6038 & 0.0000 \\
GI & I(1) & -6.3225 & 0.0000 \\
GINV & I(0) & -3.2548 & 0.0244 \\
\hline
\end{tabular}

Before executing the ARDL model, firstly, the present study checked the co-integration among the variables by using ADRL bound test, and the results show that calculated f-statistics that is 11.244 is higher than the critical values that are the indication of co-integration exist in the model. These values are highlighted in Table 5. 
Table 5

ARDL Bound Test

\begin{tabular}{cccccc}
\hline Model & F-statistics & Lag & $\begin{array}{l}\text { Level of } \\
\text { Significance }\end{array}$ & \multicolumn{2}{c}{ Bound test critical values } \\
\hline \multirow{2}{*}{ EG/(GC,FDI,GS,GI,GINV) } & \multirow{2}{*}{11.244} & \multirow{2}{*}{4} & $1 \%$ & $\mathbf{I}(\mathbf{0})$ & $\mathbf{I ( 1 )}$ \\
& & & $5 \%$ & 3.06 & 4.15 \\
& & & $10 \%$ & 2.39 & 3.38 \\
& & & & 2.08 & 3.00 \\
\hline
\end{tabular}

Firstly, the results show the short-run nexus, and the figures exposed that green financial development such as green credit, green securities, green insurance, green investment and foreign direct investment has a positive association with economic growth of Pakistan. These values are sown in Table 6.

Table 6

Short-run Relationships

\begin{tabular}{lrcrr}
\hline Variable & Coefficient & Std. Error & t-Statistic & \multicolumn{1}{c}{ Prob. } \\
\hline D(FDI) & 0.885067 & 0.129770 & 6.820258 & 0.0000 \\
D(INV) & 0.687502 & 0.185064 & 3.714938 & 0.0034 \\
D(GC) & 1.330038 & 0.344074 & 3.865560 & 0.0026 \\
D(GI) & 0.759673 & 0.115374 & 6.584416 & 0.0000 \\
D(GS) & 0.232976 & 0.062423 & 3.732225 & 0.0033 \\
CointEq(-1)* & -0.744009 & 0.176260 & -4.221088 & 0.0000 \\
R-squared & 0.963425 & Mean dependent var & & 0.032358 \\
Adjusted R-squared & 0.926850 & S.D. dependent var & & 0.299073 \\
\hline
\end{tabular}

Secondly, the results also show the long-run nexus, and the figures exposed that green credit, green securities, and green investment have a positive association with economic growth of Pakistan in long-run while green insurance and FDI are insignificantly linked with economic growth. These values are sown in Table 7.

Table 7

Long-run Relationships

\begin{tabular}{|c|c|c|c|c|}
\hline Variable & Coefficient & Std. Error & t-Statistic & Prob. \\
\hline$\overline{F D I}$ & 0.255728 & 0.158751 & 1.610873 & 0.1355 \\
\hline GC & 1.999857 & 0.320272 & 6.244240 & 0.0001 \\
\hline GI & 0.121228 & 0.141635 & 0.855916 & 0.4103 \\
\hline GINV & 0.007724 & 0.004127 & 1.871506 & 0.0881 \\
\hline GS & 0.456373 & 0.100663 & 4.533691 & 0.0009 \\
\hline C & 1.704525 & 0.677422 & 2.516193 & 0.0287 \\
\hline
\end{tabular}

Table 8

Granger Casualty

\begin{tabular}{lcccc}
\hline Null Hypothesis & Obs. & F-Statistic & Prob. & Decisions \\
\hline FDI does not Granger Cause EG & 39 & 3.52728 & 0.0413 & \\
EG does not Granger Cause FDI & 39 & 1.57250 & 0.2231 & Unidirectional \\
GC does not Granger Cause EG & 39 & 3.76331 & 0.0341 & \\
EG does not Granger Cause GC & 39 & 3.11672 & 0.0480 & Bidirectional \\
GI does not Granger Cause EG & & 2.19150 & 0.1282 & \\
EG does not Granger Cause GI & 39 & 0.35907 & 0.7011 & NO \\
GINV does not Granger Cause EG & & 0.80744 & 0.4549 & \\
EG does not Granger Cause GINV & 39 & 4.84777 & 0.0145 & Unidirectional \\
GS does not Granger Cause EG & & 0.78999 & 0.4625 & \\
EG does not Granger Cause GS & & 3.64280 & 0.0376 & Unidirectional \\
\hline
\end{tabular}


The results of Granger casualty show that GC and EG have bidirectional links with each other while FDI and EG, GINV and EG and GS and EG have unidirectional links with each other and GI and EG have no casual links with each other. These are shown in Table 8.

\subsection{Discussions}

The study findings have revealed that the green financial development in the form of issuance of green credit puts strong positive influences on the economic growth of a country. The act of bringing positive changes in their credit policies considering the environmental needs cause sustainability in economic activities both in short and long run. These results are in line with the past studies of Jin and Mengqi (2011) according to which the initiation of green credit ensures a healthy workforce for the economy and thereby, gives the economy an opportunity to compete with world economies. Moreover, these results match with the studies of Hu and Cao (2011) that give deep insight into the paramount role of green credit in the green financial development and economic growth of the country. Similarly, the results have indicated that green financial development through the issuance of green securities positively contributes to the country's economic growth both in short and long run. These results are in line with the studies of Porfir'ev (2016) which also prove that green financial development in the form of ecofriendly securities leads to a high rate of economic growth. The past studies of Berensmann and Lindenberg (2016) support these results as they also conclude in the significant role of ecofriendly securities in the achievement of a high GDP rate which determines the higher economic position of the country. Moreover, it has been indicated by the results that green financial development with the introduction of green insurance is have a positive impact on economic growth rate in short run. These results match with the studies of C. Wang, Nie, Peng, and Li (2017) which also shows the development of green insurance as a great contributor to economic growth. These results also match with the studies of Landini (2014) which show the significance of green insurance of the vehicle, accommodation, and business organizational building along with equipment. Additionally, the study results have indicated the positive contribution of investment in eco-friendly projects to the economic growth rate both in short and long run. These results are approved by the studies of Mielke and Steudle (2018) which reveal that the investment in the projects which ensures the reduction of pollution, wastes, and toxic material leads to acceleration in the economic growth rate of the country. Furthermore, the results have shown that foreign direct investment makes a positive contribution to the country's economic growth in short-run. These results are approved by the past studies of Asiedu and Lien (2011) which indicate that the investment by foreign people in the raises the financial resources of domestic business which can be used in the environmental projects leading higher economic growth.

\subsection{Theoretical Contribution and Practical Implications}

As empirical and as well as theoretical literature on the green finance and its impacts on the economy is scares. This study contributes directly to the body of literature on green finance and to the sustainable economic development indirectly when every country is striving to achieve green growth. This study is of pioneer nature which sheds light on the importance of the green credit, green insurance, green security, and green investment to improve the level of economic growth in Pakistan. This study is also a stimulus for the economists and policy makers to understand the importance of green financial development in the country to boost the economic growth accordingly. On the empirical grounds, this study provides evidence that green credit, green securities, green insurance, and green investment in eco-friendly projects are essential for economic growth in Pakistan. Therefore, this study is also a policy guideline for the regulators working in financial sector of Pakistan to ensure the green aspect of financial development in Pakistan which is the one of the major ingredients of the economic growth. 


\section{Conclusion}

This paper is aimed to highlight the importance of green finance for the economic growth in Pakistan. Therefore, this study estimated the impact of green financial development on economic growth in Pakistan for the period 1981 - 2019. Different measures of green finance have been used to capture the green aspect of financial development. These measure are green credit which is percentage of green credit to the total loans issued by the banking sector in Pakistan, green securities measured as percentage of total market value of environmentally protected companies to the total market value of all shares listed on the stock market, green insurance as percentage of agriculture insurance expenditures to total insurance expenditures, and green investment which is measured as percentage of fiscal expenditures of energy-saving and environmental protection industries to total fiscal expenditures. Along with these proxies of green financial development, impact of foreign direct investment economic growth of Pakistan is assessed in this study. Augmented Dickey Fuller (ADF) test applied to check the stationarity of the time series. After testing for the unit root problem, Autoregressive Distributive Lag Model is applied to estimate the intended relationship among green financial development and economic growth. The estimated results of ARDL showed that green credit, green investment, and green securities have positive and significant impact on economic growth. Whereas foreign direct investment and green insurance have also positive but insignificant effect on economic growth in Pakistan.

The present study highlights the importance of green credit in economic growth of Pakistan. The positive impact of green credit on economic growth suggests that credit policies of financial institutions should be eco-friendly that will be result in less contaminated material, harmful chemicals, hazardous gas, and by this means economic growth will be enhances. Likewise, green securities will also increase the economic growth as such securities encourage the business enterprises to start eco-friendly projects which will enhance performance of the economy. The green insurance facilitates the economic organizations as it provides eco-friendly vehicles, technology, accommodation, and business building either on discount or through the replacement of traditional vehicles, technology, and building after bearing the loss. Therefore, green insurance schemes in all sectors of the economy should also be encouraged. Foreign direct investment should also be channelized towards eco-friendly projects that will help the business organizations to contribute better to the economic growth of the country.

\subsection{Limitations and Future Directions}

Even though the existent research study has made excellent contribution to the theoretical as well as an empirical literature on the green finance, still there are some limitations of this study which can be addressed by future research. Although this study used four different measures of green financial development, but it is still needed to have a comprehensive and sophisticated measure or index of green financial development. Future research must focus on the development of such indices as these indices will be very helpful in analyzing the effects of green finance on the different sectors of the economy. In this study empirical model is just comprised of the green financial development but future studies must include the labor, capital, and technological innovation as independent variables along with green financial development measures to have theoretical ground for economic growth model. Further studies can also be conducted on disaggregated levels for different sectors of the economy. The data in support of this study has been collected from limited financial and industrial organizations of Pakistan, thus, for deep insight into the concerned variables and their impact on the economy, the supportive data must be collected from more organizations and as Pakistan has the different cultural and economic condition and geography as compared with other countries, the current study may not be equally suitable for all the countries. So, future scholars are recommended to expand the scope of their study by observing the same variable in other countries and their influences on the economic growth of the respective country. 


\section{References}

Ahmad, R., Hussain, A., Umer, M., \& Parveen, K. (2017). Efficiency of microfinance providers in Pakistan: An empirical investigation. Review of Economics and Development Studies, 3(2), 147-158.

Aizawa, M., \& Yang, C. (2010). Green credit, green stimulus, green revolution? China's mobilization of banks for environmental cleanup. The Journal of Environment \& Development, 19(2), 119-144.

Alfaro, L., Chanda, A., Kalemli-Ozcan, S., \& Sayek, S. (2010). Does foreign direct investment promote growth? Exploring the role of financial markets on linkages. Journal of Development Economics, 91(2), 242-256.

Asiedu, E., \& Lien, D. (2011). Democracy, foreign direct investment and natural resources. Journal of international economics, 84(1), 99-111.

Berensmann, K., \& Lindenberg, N. (2016). Green finance: actors, challenges and policy recommendations. German Development Institute/Deutsches Institut für Entwicklungspolitik (DIE) Briefing Paper, 23, 342-363.

Chandio, A. A., Jiang, Y., \& Rehman, A. (2019). Energy consumption and agricultural economic growth in Pakistan: is there a nexus? International Journal of Energy Sector Management, 13(3), 597-609.

Eyraud, L., Clements, B., \& Wane, A. (2013). Green investment: Trends and determinants. Energy Policy, 60, 852-865.

Hassan, M. K., Sanchez, B., \& Yu, J.-S. (2011). Financial development and economic growth: New evidence from panel data. The Quarterly Review of economics and finance, 51(1), 88-104.

Hassan, S. T., Xia, E., Khan, N. H., \& Shah, S. M. A. (2019). Economic growth, natural resources, and ecological footprints: evidence from Pakistan. Environmental Science and Pollution Research, 26(3), 2929-2938.

He, L., Liu, R., Zhong, Z., Wang, D., \& Xia, Y. (2019). Can green financial development promote renewable energy investment efficiency? A consideration of bank credit. Renewable Energy, 143, 974-984.

Hu, N., \& Cao, D. (2011). Green credit policy and environmental risk management of commercial Banks. Econ. Probl, 3, 26-37.

Jin, D., \& Mengqi, N. (2011). The paradox of green credit in China. Energy Procedia, 5, 19791986.

Karásek, J., \& Pavlica, J. (2016). Green investment scheme: Experience and results in the Czech Republic. Energy Policy, 90, 121-130.

Kuo, C.-F. J., Lin, C.-H., \& Hsu, M.-W. (2016). Analysis of intelligent green building policy and developing status in Taiwan. Energy Policy, 95, 291-303.

Landini, S. (2014). Green Motor Insurance. Eur. Energy \& Envtl. L. Rev., 23, 198-206.

Liu, R., Wang, D., Zhang, L., \& Zhang, L. (2019). Can green financial development promote regional ecological efficiency? A case study of China. Natural Hazards, 95(1-2), 325-341.

Liu, X., Wang, E., \& Cai, D. (2019). Green credit policy, property rights and debt financing: Quasi-natural experimental evidence from China. Finance Research Letters, 29, 129-135.

Luqman, M., Ahmad, N., \& Bakhsh, K. (2019). Nuclear energy, renewable energy and economic growth in Pakistan: Evidence from non-linear autoregressive distributed lag model. Renewable Energy, 139, 1299-1309.

Martin, P. R., \& Moser, D. V. (2016). Managers' green investment disclosures and investors' reaction. Journal of Accounting and Economics, 61(1), 239-254.

Mielke, J., \& Steudle, G. A. (2018). Green Investment and Coordination Failure: An Investors' Perspective. Ecological Economics, 150, 88-95.

Moran, T. (2012). Foreign direct investment. The Wiley-Blackwell Encyclopedia of Globalization, 4, 1-9.

Nawaz, M. A., Hussain, M. S., Kamran, H. W., Ehsanullah, S., Maheen, R., \& Shair, F. (2020). Trilemma association of energy consumption, carbon emission, and economic growth of 
BRICS and OECD regions: quantile regression estimation. Environmental Science and Pollution Research. doi:10.1007/s11356-020-11823-8

Nawaz, M. A., Seshadri, U., Kumar, P., Aqdas, R., Patwary, A. K., \& Riaz, M. (2020). Nexus between green finance and climate change mitigation in $\mathrm{N}-11$ and BRICS countries: empirical estimation through difference in differences (DID) approach. Environmental Science and Pollution Research. doi:10.1007/s11356-020-10920-y

Nawaz, M. A., Yousaf, W., Hussain, M. S., \& Riaz, M. (2020). Effect of tourism growth on CO2 emissions and economic growth in South Asian countries: A panel GMM approach. Hamdard Islamicus, 43(1), 471-483.

Porfir'ev, B. (2016). Green trends in the global financial system. Mirovaya ekonomika $i$ mezhdunarodnye otnosheniya, 60(9), 5-16.

Rydqvist, K., Spizman, J., \& Strebulaev, I. (2014). Government policy and ownership of equity securities. Journal of Financial Economics, 111(1), 70-85.

Shah, M. (2019). Green human resource management: Development of a valid measurement scale. Business Strategy and the Environment, 28(5), 771-785.

Shahbaz, M., Khan, S., \& Tahir, M. I. (2013). The dynamic links between energy consumption, economic growth, financial development and trade in China: fresh evidence from multivariate framework analysis. Energy Economics, 40, 8-21.

Shahbaz, M., Nasreen, S., Abbas, F., \& Anis, O. (2015). Does foreign direct investment impede environmental quality in high-, middle-, and low-income countries? Energy Economics, $51,275-287$.

Shair, F., Shaorong, S., Kamran, H. W., Hussain, M. S., Nawaz, M. A., \& Nguyen, V. C. (2021). Assessing the efficiency and total factor productivity growth of the banking industry: do environmental concerns matters? Environmental Science and Pollution Research. doi: $10.1007 / \mathrm{s} 11356-020-11938-y$

Sörensen, J., \& Emilsson, T. (2019). Evaluating flood risk reduction by urban blue-green infrastructure using insurance data. Journal of Water Resources Planning and Management, 145(2), 99-117.

Sun, H., Awan, R. U., Nawaz, M. A., Mohsin, M., Rasheed, A. K., \& Iqbal, N. (2020). Assessing the socio-economic viability of solar commercialization and electrification in south Asian countries. Environment, Development and Sustainability. doi:10.1007/s10668-02001038-9

Tan, H., Chen, S., Shi, Q., \& Wang, L. (2014). Development of green campus in China. Journal of Cleaner Production, 64, 646-653.

Wang, C., Nie, P.-y., Peng, D.-h., \& Li, Z.-h. (2017). Green insurance subsidy for promoting clean production innovation. Journal of Cleaner Production, 148, 111-117.

Wang, F., Yang, S., Reisner, A., \& Liu, N. (2019). Does Green Credit Policy Work in China? The Correlation between Green Credit and Corporate Environmental Information Disclosure Quality. Sustainability, 11(3), 733-747.

Wang, H., \& Bernell, D. (2013). Environmental disclosure in China: An examination of the green securities policy. The Journal of Environment \& Development, 22(4), 339-369.

Yong-hui, W. (2010). On the Perfection of Green Securities System of Our Country [J]. Journal of Luoyang Institute of Science and Technology (Social Science Edition), 6, 452-471.

ZENG, D.-h., \& ZHANG, P.-a. (2011). Evolutionary Game Analysis of Green Insurance Subject. Science Technology and Engineering, 11(31), 1671-1815.

Zhang, J., Wang, L., \& Wang, S. (2012). Financial development and economic growth: Recent evidence from China. Journal of Comparative Economics, 40(3), 393-412. 